\title{
Future Medicine such as Gene or Stem Cell Therapy are Better than Nonbiological or Some Biological (Antibiotic) Medicine
}

\author{
Ilkram Hasan* \\ Department of pharmacy, Bgc trust university Bangladesh, Bangladesh
}

Submission: December 20, 2016; Published: January 18, 2017

*Corresponding author: Ikram Hasan*, Department of pharmacy, Bgc trust university Bangladesh, Bangladesh, Tel: 1811385272;

Email: ikramhasann@gmail.com

\section{Introduction}

Gene therapy is the therapy where nucleic acid polymers are used to delivery into patient's cell as a drug to treat the disease and using an adenovirus vector which is insert the new gene into cell and this gene make a functional protein to treat or control of the disease and it is also used to treat the cancer or hormonal diseases $[1,2]$. On the other hand, stem cell therapy is the therapeutic delivery of stem cell into patient's body to treat or prevent of the disease or condition such as blood stem cell used to treat the blood diseases and it is also known as regenerative medicine $[3,4]$. Stem cell grow in a lab and manipulated of specialize cell into specific types cell such as heart muscle cells,blood cells,nerve cells [4,5]. In case of defective or injured heart muscle cell,stem cell contributes to repairing defective or injured heart muscle cells $[6,7]$.

Non biological drug are chemical substance which obtained by chemical synthesis processes and their structure is known and it is used to treatment of diseases,cure of disease,control of diseases.non biological drugs such as losartan,metformin,atenolol,propranolol,paracetamol,ranitidine atropine etc bind with receptor or enzyme and stimulate or inhibit the receptor or enzyme and give desire action [8-10]. On the other hand, antibiotic (biological drug) are chemical substance which obtain from biological sources such as differents microorganism
[11,12]. Antibiotic such as penicillin,cephalosporin are used to growth inhibit or kill of the microorganism but at present,antibiotic are resistance by microorganism and Non biological drug gradually decrease their efficacy and so in future gene therapy and stem cell therapy are more dependable than antibiotic or Non biological drug [1,3,4,9,10,13,14].

\section{Method}

For the purpose of research work, 20 specimens are divided into 2 groups. 1st group for Non biological drug study and contain 10 specimens (patient's) and $2^{\text {nd }}$ group for biological (antibiotic) drug study and contain 10 specimens.

\section{Non Biological Drug Study}

$1^{\text {st }}$ group (Non biological drug) are sub divided into 3 group such as A,B,C group.A group contained 3 specimen (patient's) and patient's had hypertention disease and applied antihypertensive drug such as losartan, bisoprolol; B group contained 3 specimen(patient's) and patient's had diadetes disease and applied antidiabetes drug such as metformin,glibenclamide; $\mathrm{C}$ group contained 4 specimen (patient's) and patient's had asthma disease and applied antiasthmatic drug such as theophylline,inhaler. $1^{\text {st }}$ group had been monitoring for 4 years and recorded their dose requirement and disease condition (Table 1).

Table 1: Nonbiological drug study and increase the amount of dose for disease control.

\begin{tabular}{|c|c|c|c|c|c|c|}
\hline Patient's no. & $\begin{array}{c}\text { Sex and } \\
\text { age } \\
\text { (during } \\
\text { initial } \\
\text { dose) }\end{array}$ & $\begin{array}{c}\text { Drug name } \\
\text { (primary) }\end{array}$ & Disease & $\begin{array}{c}\text { Initial dose for } \\
\text { disease control } \\
\text { per /day }\end{array}$ & $\begin{array}{c}\text { After } 3 \text { years, dose for } \\
\text { disease control/day }\end{array}$ & $\begin{array}{c}\text { After 4 years, dose for } \\
\text { disease control/day }\end{array}$ \\
\hline 01 (group-A) & Male, 58 & Losartan & Hypertension & Losartan $50 \mathrm{mg}$ & Losartan $100 \mathrm{mg}$ & $\begin{array}{c}\text { Losartan } 100 \mathrm{mg}+\mathrm{bisoprolol} \\
2.5 \mathrm{mg}\end{array}$ \\
\hline 02 (group-A) & Male, 55 & Losartan & Hypertension & Losartan $50 \mathrm{mg}$ & Losartan $100 \mathrm{mg}$ & $\begin{array}{c}\text { Losartan } 100 \mathrm{mg}+\mathrm{bisoprolol} \\
5 \mathrm{mg}\end{array}$ \\
\hline
\end{tabular}




\section{Global Journal of Pharmacy \& Pharmaceutical Sciences}

\begin{tabular}{|c|c|c|c|c|c|c|}
\hline 03 (group-A) & Male, 52 & Losartan & Hypertension & Lorsartan 50mg & Losartan 100mg & Losartan $100 \mathrm{mg}$ \\
\hline 04 (group-B) & Male, 47 & Metformin & Type-2, diabetes & Metformin 500mg & Metformin $1000 \mathrm{mg}$ & Metformin $1000 \mathrm{mg}$ \\
\hline 05 (group-B) & $\begin{array}{l}\text { Female, } \\
\quad 45\end{array}$ & Metformin & Type-2, diabetes & Metformin 500mg & $\begin{array}{c}\text { Metformin } 500 \\
\text { mg+glibenclamide } 5 \mathrm{mg}\end{array}$ & $\begin{array}{c}\text { Metformin } \\
1000 \mathrm{mg}+\text { glibenclamide } 5 \mathrm{mg}\end{array}$ \\
\hline 06 (group-B) & Male, 55 & Metformin & Type-2, diabetes & Metformin $500 \mathrm{mg}$ & Metformin $1000 \mathrm{mg}$ & $\begin{array}{l}\text { Metformin } 1000 \mathrm{mg}+ \\
\text { glibenclamide } 5 \mathrm{mg}\end{array}$ \\
\hline 07 (group-C) & Male, 45 & Theophyline & Asthma & $\begin{array}{l}\text { Theophylline } \\
\text { 200mg } \\
\text { +sometimes } \\
\text { inhaler }\end{array}$ & $\begin{array}{l}\text { Theophylline } 400 \mathrm{mg} \\
\text { +sometimes inhaler } \\
\text { (Salbutamol) }\end{array}$ & $\begin{array}{l}\text { Theophylline } 400 \mathrm{mg}+ \\
\text { inhaler (regular) }\end{array}$ \\
\hline 08 (group-C) & $\begin{array}{l}\text { Female, } \\
59\end{array}$ & Theophyline & Asthma & $\begin{array}{l}\text { Theophylline } 200 \\
\text { mg + inhaler }\end{array}$ & $\begin{array}{l}\text { Theophylline } 400 \mathrm{mg}+ \\
\text { inhaler }\end{array}$ & $\begin{array}{l}\text { Theophylline } 400 \mathrm{mg}+ \\
\text { inhaler+prednisolone }\end{array}$ \\
\hline 09 (group-C) & Male, 55 & Theophylline & Asthma & $\begin{array}{l}\text { Theophylline } 400 \\
\text { mg }\end{array}$ & Theophylline $400 \mathrm{mg}+$ inhaler & Theophylline $400 \mathrm{mg}+$ inhaler \\
\hline 10 (group-C) & $\begin{array}{l}\text { Female, } \\
\quad 61\end{array}$ & Theophylline & Asthma & $\begin{array}{c}\text { Theophylline } 400 \\
\text { mg+sometimes } \\
\text { inhaler }\end{array}$ & $\begin{array}{c}\text { Theophylline } \\
\text { 400mg+inhaler+prednisolon }\end{array}$ & $\begin{array}{c}\text { Theophylline } \\
400 \mathrm{mg}+\text { inhaler+prednisolon }\end{array}$ \\
\hline
\end{tabular}

\section{Biology (Antibiotic) Drug Study}

$2^{\text {nd }}$ group is subdivided into 5 groups such as $A, B, C, D$, E. This 5 subdivided group sample was sent to the different diagnostic center for culture test (antibiotic resistance test). A group had 2 specimens (A1,A2). A1, A2 urine sample (due to UIT symptom show) was sent to modern diagnostic centre Ltd (Dhaka, Bangladesh), B group had 2 specimen(B1,B2).B1,B2 urine sample(due to UIT symptom show) was sent to meghna laboratory (Chittagong, Bangladesh), C group had 2 specimen (C1,C2). C1, C2 sputum sample (due to RTI symptom show) was sent to chevron diagnostic centreLmd (Chittagong,Bangladesh), D group had 2 specimen (D1, D2). D1, D2 blood sample (due to several surgical wound infection) was sent to sigma laboratory Ltd (Chittagong, Bangladesh), E group had 2 specimen (E1,E2). E1, E2 blood sample (due to high fever, stomach pain) was sent to CSCR diagnostic centre Ltd (chittagong, Bangladesh) and report was collected and recorded (Table 2).

Table 2: Antibiotic (biological) drug study and different antibiotic resistance show.

\begin{tabular}{|c|c|c|c|c|}
\hline Specimen no. & $\begin{array}{l}\text { Age and sex } \\
\text { (male or } \\
\text { female) }\end{array}$ & Organism & Resistance to drug & $\begin{array}{l}\text { Test and } \\
\text { specimen } \\
\text { location }\end{array}$ \\
\hline $\begin{array}{l}01 \\
\text { (sample-A1) }\end{array}$ & 20 , female & Esch.coli & $\begin{array}{l}\text { Amoxicillin, cotrimoxazole, cephalexin, cepharadine, ceftriaxone, } \\
\text { ceftazidime, ciprofloxacin, nalidixic acid. }\end{array}$ & Bangladesh \\
\hline $\begin{array}{c}02 \\
\text { (sample-A2) }\end{array}$ & 30, male & Esch. Coli & $\begin{array}{l}\text { Amoxicillin, cephalexin, cotrimoxazole, ciprofloxacin, ampicillin, } \\
\text { vancomycin, ceftriaxone. }\end{array}$ & Bangladesh \\
\hline $\begin{array}{c}03 \\
\text { (sample-B1) }\end{array}$ & 13, male & $\begin{array}{l}\text { Coliform } \\
\text { bacteria }\end{array}$ & $\begin{array}{l}\text { Azithromycin, ceftrioxane, Cefepime, doxycycline, } \\
\text { gentamycin, nitrofurantoin.. }\end{array}$ & Bangladesh \\
\hline $\begin{array}{l}04 \\
\text { (sample-B2) }\end{array}$ & 20, male & $\begin{array}{l}\text { Coliform } \\
\text { bacteria }\end{array}$ & $\begin{array}{l}\text { Vancomycin,chloramphenicol,azithromycin,ceftioxane, } \\
\text { doxycycline,gentamycin,nitrofurantoin. }\end{array}$ & Bangladesh \\
\hline $\begin{array}{l}05 \\
\text { (sample-C1) }\end{array}$ & 25 , female & $\begin{array}{l}\text { Staphylococcus } \\
\text { aureus }\end{array}$ & $\begin{array}{c}\text { Ampicillin, Cloxacillin, vancomycin, tetracycline, chloramphenicol, } \\
\text { methicillin. }\end{array}$ & Bangladesh \\
\hline $\begin{array}{c}06 \\
\text { (sample-C2) }\end{array}$ & 30, male & $\begin{array}{l}\text { Staphylococcus } \\
\text { aureus }\end{array}$ & Methicillin, ampicillin, erythromycin, Cloxacillin, tetracycline, vancomycin. & Bangladesh \\
\hline $\begin{array}{l}07 \\
\text { (sample-D1) }\end{array}$ & 35, male & $\begin{array}{l}\text { Streptococcus } \\
\text { pyogenes }\end{array}$ & $\begin{array}{l}\text { Clindomycin, tetracycline, erythromycin, chloramphenicol, } \\
\text { clarithromycin, cephalexin. }\end{array}$ & Bangladesh \\
\hline $\begin{array}{l}08 \\
\text { (sample-D2) }\end{array}$ & 20 , female & $\begin{array}{l}\text { Streptococcus } \\
\text { pyogenes }\end{array}$ & $\begin{array}{l}\text { Tetramycin,clindamycin,erythromycin,clarithromycin, } \\
\text { vancomycin,cephalexin,chloramphenicol. }\end{array}$ & Bangladesh \\
\hline $\begin{array}{l}09 \\
\text { (sample-E1) }\end{array}$ & 29, male & $\begin{array}{l}\text { Salmonella } \\
\text { typhi }\end{array}$ & $\begin{array}{l}\text { Ampicillin, amoxicillin, cephalexin, cepharadine, ceftriaxone, cotimoxazole, } \\
\text { chloramphenicol, ciprofloxacin, sulphamethoxazole, nalidixic acid. }\end{array}$ & Bangladesh \\
\hline $\begin{array}{l}10 \\
\text { (sample-E2) }\end{array}$ & 32 , male & $\begin{array}{l}\text { Salmonella } \\
\text { typhi }\end{array}$ & $\begin{array}{l}\text { Ampicillin, amoxicillin. Cephalexin, cephraradine, cotimoxazole, } \\
\text { chloramphenicol, sulphamethoxazole, nalidixic acid, oxacillin, clindomycin }\end{array}$ & Bangladesh \\
\hline
\end{tabular}




\section{Global Journal of Pharmacy \& Pharmaceutical Sciences}

Result

\section{Non biological drug study \\ Biology (antibiotic) drug study}

The study of the result shows that the drugs both some biological (only antibiotic or antimicrobial agent) and Non biological drug are gradually decrease their efficacy. Biological drug such as antimicrobial agent,antibiotic are gradually resistance by microorganism. After 20 to 40 years later 60 to 90 percent antibiotic or antimicrobial agent will be resistance by microorganism. Non biological drug could not bind properly with their specific receptor due to structural change of receptor or decrease the affinity of drug to receptor. After 30 to 40 years later the drug efficacy gradually decrease at low level and show low therapeutic effect. At this time the innovative treatment such as gene therapy,stem cell therapy are the more dependable treatment for control or prevent or cure of the diseases. Specific gene therapy used for specific disease control or cure.Manipulation of gene in the human cell and produce protective agent such as protein, antibody, enzyme) which inhibit the growth or kill of the microorganism and also control the hormonal diseases and cellular function and this protective agent such as protein which bind with receptor (structural change receptor which could not bind with Nonbiological drug) and give the desire function. On the other hand,stem cell therapy which control the all abnormal cell such as cancer cell,hormonal abnormal cell etc. and prevent the diseases and give the desires cellular function.

\section{Discussion}

Nonbiological drug are synthetic compounds which could not derived from living organism and which bind with receptor, enzyme and show their desire action $[9,10]$. The long time use of Nonbiological drug are gradually decrease their efficacy due to decrease the affinity of drug to receptor or structural change of the receptor and drug could not properly bind with receptor or enzyme and could not show their therapeutic effect $[8,10,15]$. The dose of the drug are gradually increasing day by day, at a certain time the drug could not work properly and does not give their therapeutic effect and do not improve the disease condition $[8,10,17]$. Antibiotic resistance is the ability of microorganism to stop the action of antibiotic and increase the difficulty to treat the infectious diseases [12,15]. Antibiotic resistance due to the genetic mutation of microorganism,resistance gene transfer one microorganism to another microorganism, misuse of antibiotic, production of enzyme by microorganism $[11,18]$.

Antibiotic resistance is increasing day by day such as staphylococcus aureus resistant the methicillin, penicillin, Cloxacillin, erythromycin, tetracycline, vancomycin and streptococcus pyogene resistant the tetracycline, erythromycin, clindamycin, vancomycin, chloramphenicol and Esch. Coli resistant the amoxicillin, cephalexin, ciprofloxacin, nalidixic acid, cephradin, cotrimoxazole and coliform bacteria resistant the tetracyclin, ampicillin, azithromycin, doxycycline, gentamycin and salmonella typhi resistant the chloramphenicol, ampicillin, ciprofloxacin, tetracyclin, vancomycin, amoxicillin, cephalexin, cephradin.after 20-30 year later 50-70 percent antibiotic will be resistance and 40-50 year later 70-90 percent antibiotic will be resistance and many people die due to infectious diseases $[11,12,14,19]$.

Gene therapy is the manipulation of the gene into the cell and gives the desired functional protein (enzyme,antibody, hormone) which control or prevent the diseases such as manipulation of tumor suppression gene, which control the tumor or cancer diseases,manipulation of antibody producing gene, which inhibit the growth or kill the microorganisms [1,13,20]. Manipulation of gene can also control all genetic diseases and strong the immune system and control all hormonal diseases [1,2].

Stem cell have the ability of regeneration of cell such as regeneration of brain cell for the treatment of Parkinson's diseases, Alzheimer's diseases and other brain diseases. Blood stem cell can regeneration of blood cell for the treatment of blood cancer cell $[3,4]$. Diabetes patient's could not produce insulin due to the lack of function of insulin producing beta cell and by stem cell therapy, beta cell can be regeneration and produce insulin and control the diabetes disease [6,7]. Stem cell may be advance in future and control the cellular problem and other diseases $[4,5]$. The findings of the study showed that day by day nonbiological drug efficacy are gradually decrease and amount of dose gradually increase $[8,10]$. At a certain time,Non biological drug could not work in our body and could not give the desire therapeutic action $[15,16]$. On the hand,day by day antibiotic resistant are gradually increase $[12,14]$. At a certain time,antibiotic could not work in our body and could not kill the microorganism and many people dies due to infectious diseases $[11,12]$. At this time,the innovative treatment such as gene therapy or stem cell therapy are most dependable treatment for the prevent or control of the diseases condition and safe the life of the people $[1,3,4,13]$.

\section{Conclusion}

In future non biological drug could not work properly in our body and antibiotic resistance may be 70-90 percent(30-50 year later) and many people dies due to diseases could not improve $[8,14,16]$. At this time the innovative treatment such as gene therapy or stem cell therapy are most dependable treatment for the treatment of diseases condition $[1,6,7]$.

\section{References}

1. Friedmann T, Roblin R (1972) Gene Therapy for Human Genetic Disease?. Science 175 (4025): 949-955.

2. Human Cloning and Genetic Modification (2013) Association of Reproductive Health Official.

3. Gurtner G, Callaghan MJ, Longaker MT (2007) Progress and potential for regenerative medicine. Annu Rev Med 58 (1): 299-312.

4. Ptaszek LM, Mansour M, Ruskin JN, Chien KR (2012) Towards 
regenerative therapy for cardiac disease. The Lancet 379 (9819): 933 942

5. Malliaras K, Kreke M, Marban E (2011) The stuttering progress of cell therapy for heart disease. Clin Pharmacol Ther 90(4): 532-541.

6. Giarratana MC, Kobari L, Lapillonne H, Chalmers D, Kiger L, et al (2005) Ex vivo generation of fully mature human red blood cells from hematopoietic stem cells. Nat Biotechnol 23(1): 69-74

7. Yousef M, Schannwell CM, Köstering M, Zeus T, Brehm M, et al. (2009) The BALANCE Study: clinical benefit and long-term outcome after intracoronary autologous bone marrow cell transplantation in patients with acute myocardial infarction. J Am Coll Cardiol 53(24): 2262-2269.

8. Schellekens H, Klinger E, Mühlebach S, Brin JF, Storm G, et al. (2011)The therapeutic equivalence of complex drugs.Regul Toxicol Pharmacol 59(1): 176-183

9. Beat Flühmann, Daan JA, Crommelin, Jon SB de Vlieger, Gerrit Borchard Stefan Mühlebach, et al. (2013) The authorization of non-biological complex drugs (NBCDs) follow-on versions: specific regulatory and interchangeability rules ahead? Jabber Journal 2(4): 204-207.

10. Daan JA Crommelin, John SB de Vlieger (2015) Epilogue: What Did We Learn? What Can We Expect in the Future? Concluding Remarks and Outstanding Issues. Non-Biological Complex Drugs pp. 381-388.
11. Andersson D, Hughes D (2011) Persistence of antibiotic resistance in bacterial populations. FEMS Microbiol Rev 35(5): 901-911.

12. Annual Report of the Chief Medical Officer (2013) Infections and the rise of antimicrobial resistance" (PDF). UK NHS. 2011.

13. Cavazzana-Calvo M, Thrasher A, Mavilio F (2004) The future of gene therapy Nature 427(6977): 779-781.

14. Stuart B Levy (2002) Factors impacting on the problem of antibiotic resistance. J Antimicrob Chemother 49 (1): 25-30.

15. Borchar G, Flühmann B, Mühlebach S (2012) Nanoparticle iron medicinal products-Requirements for approval of intended copies of non-biological complex drugs (NBCD) and the importance of clinical comparative studies. Regul Toxicol Pharmacol 64(2): 324-328.

16. Biggest Threats - Antibiotic/Antimicrobial Resistance - CDC.

17. Tacconelli E, De Angelis G, Cataldo MA, Pozzi E, Cauda R (2008) Does antibiotic exposure increase the risk of methicillin-resistant Staphylococcus aureus (MRSA) isolation? A systematic review and meta-analysis. J Antimicrob Chemother 61(1): 26-38.

18. Herper, Matthew (2014) Gene Therapy's Big Comeback Forbes.

19. Gene Therapy Clinical Trials Worldwide Database. The Journal of Gene Medicine Wiley (2016).

Your next submission with Juniper Publishers
will reach you the below assets
- Quality Editorial service
- Swift Peer Review
- Reprints availability
- E-prints Service
- Manuscript Podcast for convenient understanding
- Global attainment for your research
- Manuscript accessibility in different formats
( Pdf, E-pub, Full Text, Audio)
- Unceasing customer service
Track the below URL for one-step submission
https://juniperpublishers.com/online-submission.php

